\title{
Penicillin allergy evaluation: experience from Kuwait
}

\author{
Mona Al-Ahmad ${ }^{1 *}$, Tito Rodriguez Bouza ${ }^{2}$ \\ From 6th Drug Hypersensitivity Meeting (DHM 6) \\ Bern, Switzerland. 9-12 April 2014
}

\section{Background}

Hypersensitivity to penicillin has been studied worldwide, but data regarding patterns of sensitization in Arabian Gulf countries are scarce.

\section{Objectives}

To describe the patterns of penicillin hypersensitivity during a 6-years study in Kuwait in terms of demographics, type of the culprit drug, in-vivo and in-vitro allergy testing.

\section{Methods}

124 patients referred to the drug allergy clinic for penicillin allergy were fully evaluated by skin prick and intradermal testing. Drug provocation test was done on patients with negative results.

\section{Results}

Total of 124 patients were evaluated for penicillin allergy. Mean age was 37.8 (SD 12.7) years, range from 8 to 74 years. $39(31.5 \%)$ male and $85(68.5 \%)$ female patients were included. Diagnosis of penicillin allergy was confirmed in 46 patients (37.1\%). Among the 44 confirmed allergic patients by skin evaluation we had 15 (34.1\%) positive skin prick test, and 29 (65.9\%) positive intradermal testing. Among patients with positive skin testing, 47.7\% were positive to PPL, $20.4 \%$ to MDM, $50.0 \%$ to PG and $40.9 \%$ to ampicillin; $13.6 \%$ of patients were positive to amoxicillin by skin prick test. One patient had positive RAST and one had a positive challenge test.

\section{Conclusion}

Penicillin allergy is a common problem with an incidence of about one third in our cohort.

${ }^{1}$ Allergy Center, Kuwait

Full list of author information is available at the end of the article

\author{
Authors' details \\ ${ }^{1}$ Allergy Center, Kuwait. ${ }^{2}$ Al-Rashed Allergy Center, Allergy Department, \\ Kuwait.
}

Published: 18 July 2014

doi:10.1186/2045-7022-4-S3-P103

Cite this article as: Al-Ahmad and Bouza: Penicillin allergy evaluation: experience from Kuwait. Clinical and Translational Allergy 2014 4(Suppl 3): P103.
Submit your next manuscript to BioMed Central and take full advantage of:

- Convenient online submission

- Thorough peer review

- No space constraints or color figure charges

- Immediate publication on acceptance

- Inclusion in PubMed, CAS, Scopus and Google Scholar

- Research which is freely available for redistribution

Submit your manuscript at www.biomedcentral.com/submit
() Biomed Central 